\title{
Histological and Immunohistochemical Characterization of Joint Inflammation and Flare-up Reactions Induced by Cloned MT4 ${ }^{+}$, Lyt- $2^{-}$T cells
}

\author{
I. S. KLASEN, R. M. T. LADESTEIN, A. A. GRANDIA,
} TH. H. VAN DER KWAST \& R. BENNER

Departments of Immunology and Pathology, Erasmus University, Rotterdam, The Netherlands

\begin{abstract}
Klasen, I.S., Ladestein, R.M.T., Grandia, A.A., van der Kwast, TH.H. \& Benner, R. Histological and Immunohistochemical Characterization of Joint Inflammation and Flare-up Reactions Induced by Cloned MT4+, Lyt-2- T Cells. Scand. J. Immumol. 32, 281-288, 1990

This report describes the histological and immunohistochemical characterization of joint inflammations and flare-up reactions in mice induced by cloned $\mathrm{MT} 4^{+}$, Lyt $-2-\mathrm{T}$ cells. The T-cell clone used was specific for the antigen methylated bovine serum albumin (mBSA) and was inoculated locally into a joint together with the antigen. The histological examination was performed in methylmethacrylate sections, and the various cell types were quantified in distinct regions of the knee joint. The infiltrates consisted predominantly of granulocytes admixed with small numbers of histiocytes. Few lymphocytes were present, while plasma cells were not found. Fibrosis was prominent in the later stages of the inflammation.

Immunohistochemical analysis of total unfixed, non-decalcified sections using monoclonal antibodies revealed the presence of $\mathrm{T}$ cells which were predominantly of the helper phenotype, sporadic B cells, and a considerable number of Ia-positive cells. Macrophages were scattered throughout the infiltrate. The synovial lining was shown to express Ia antigens and to contain cells that stained with macrophage markers. Cell clusters were found including helper $\mathrm{T}$ (Th) cells, some B cells, and Ia-positive cells.

These results are in line with immunohistological examinations in other arthritis models and resemble the early events in human rheumatoid arthritis. The data indicate that activated helper T cells are required and sufficient to give rise to the inflammatory infiltrates that are characteristic of the inflammations and exacerbations in human rheumatoid arthritis.
\end{abstract}

Dr I. S. Klasen, Department of Immunology, PO Box 1738, 3000 DR Rotterdam, The Netherlands

Several animal models for human rheumatoid arthritis have been developed to investigate the processes that are involved in the pathogenesis and the chronicity of this inflammatory disease. The cellular composition of arthritic joints is a topic of interest of many investigators in man as well as in animal models. Human arthritis has been shown to express characteristics of a delayed-type hypersensitivity (DTH) reaction in which T cells are in close contact with class IIpositive cells [13]. The antigen-induced arthritis (AIA) model in the rat, mouse, or rabbit is a model that is frequently used. In the murine model the animals are immunized by a protein antigen emulsified in complete Freund's adjuvant
(CFA). Several weeks later the animals are challenged with the same antigen. In the case of a cationic antigen, such as methylated bovine serum albumin (mBSA), this treatment results in a chronic joint inflammation [4].

By transfer studies this phenomenon has been shown to be T-cell-mediated [5]. As the cationic antigen is retained by the negatively charged cartilage structures, $T$ cells in the inflammatory infiltrate might persist in the knee joint, resulting in a chronic inflammation [28]. Flare-up phenomena in these inflammations may be provoked by a second (local, intravenous, or oral) administration of the antigen $[20,27,29]$.

Recently, we have shown that comparable joint 
inflammations could also be induced by local inoculation of cloned $\mathrm{mBSA}$-specific $\mathrm{T}$ cells of the helper phenotype and the antigen mBSA [14, 15]. These joint inflammations also showed flare-up reactions after a second local administration of mBSA. By making use of this model, the functional importance of $T$ cells could be clearly demonstrated during the induction and the flareup reactions in AIA.

In the present study we investigated the histological and immunohistochemical appearance of the joint inflammations in this well-defined model. Histological examination revealed a predominantly granulocytic infiltrate along with smaller numbers of histiocytes and lymphocytes. For immunohistochemical analysis of the induced joint inflammations we adopted a method of tape-attached sections of total unfixed, undecalcified knee joints [8, 23, 30, 31]. Monoclonal antibodies against $\mathrm{T}$ cells ( $\mathrm{Th}$ and $\mathrm{Tc} / \mathrm{s}), \mathrm{B}$ cells, Ia antigen, and macrophages were used. During flare-up reactions the infiltrates showed T cells predominantly of the helper phenotype, few $B$ cells, and a large number of cells that expressed Ia antigens.

\section{MATERIALS AND METHODS}

Mice. Female C57BL/Ka mice were used that were obtained from Bomholtgard, Ry, Denmark, or from our own breeding stock.

Cloned $T$ cells. The production of the cloned $\mathrm{MT} 4^{+}$, Lyt-2- $\mathrm{T}$ cells and the culture conditions optimal for these $\mathrm{T}$ cells have been described previously [14, 24].

Induction of arthritis and flare-up reactions. Arthritis was induced as described previously $[14,15]$. Briefly, $3 \times 10^{5}$ or $5 \times 10^{5} \mathrm{mBSA}$-specific MT4 ${ }^{+}$, Lyt-2- cloned $\mathrm{T}$ cells were injected intra-articularly $0.5-1 \mathrm{~h}$ after the injection of $30 \mu \mathrm{g}$ of the antigen mBSA into the right knee joint and the irrelevant control antigen ovalbumin (OVA) into the left knee joint. Flare-up reactions were induced by a repeated local injection of the same amount of the antigens 2 weeks later. Twenty-four hours after the induction of joint inflammation or flareup reaction, the inflammation was quantified by the technetium- $99 \mathrm{~m}$ uptake method described by Kruysen et al. [16]. The inflammatory swellings were expressed as the specific increase of knee thickness which was designated as:

technetium uptake right joint - technetium uptake left joint technetium uptake left joint

$$
\times 100 \%
$$

Histology. Twenty-four hours after induction of joint inflammation or flare-up reaction, the right and the left knee joints of the mice were removed in toto. Similarly, the knee joints were removed from mice that had a waned joint inflammation 14 days after induction of the inflammation and that did not receive a second challenge with the antigens. The dissected joints were fixed in formaldehyde/methanol and subsequently embedded in methylmethacrylate as described previously [26]. Sections of $3 \mu \mathrm{m}$ thickness were stained by Giemsa. The sections of representative mice were examined by two independent investigators. The numbers of the various cell types in the infiltrates were determined at a total magnification of $400-800 \times$ using a counting grid in which a total of 100 cells was counted. This was done in three (first induction) or four (flare-up) separate levels of the joint. The arithmetic mean of the counts of these levels was calculated. Each section was examined in three different regions as indicated in Fig. I.

Immunohistochemistry and monoclonals. Cryostat sections $(8 \mu \mathrm{m})$ of the total unfixed, non-decalcified knee joints were made using a Bright cryostat with a tungsten carbide-tipped knife. The sections were attached to adhesive tape as has been described before $[8,23,30,31]$, attached to slides, fixed for $7 \mathrm{sec}$ in acetone (analytical grade, Merck, Darmstadt, FRG) and air-dried. Subsequently the slides were incubated with one of the monoclonal antibodies listed in Table I for $45 \mathrm{~min}$ at $4 \mathrm{C}$. Undiluted cell culture supernatants were used. Negative control slides were incubated with phosphate-buffered saline (PBS), $\mathrm{pH} 7.4$, with $0.2 \%$ bovine serum albumin (BSA) only. The slides were washed with the same PBS and incubated in the second step with peroxidase-labelled rabbit anti-rat-Ig (Dakopatts, Copenhagen, Denmark) diluted 1:40 in PBS containing $0.2 \% \mathrm{BSA}$ and $1 \%$ normal mouse serum. Peroxidase activity was visualized by incubation with 3,3'-diaminobenzidine tetrahydrochloride (DAB, Sigma, St Louis, Mo., USA). $0.5 \mathrm{mg} / \mathrm{ml}$ DAB was used in Tris- $\mathrm{HCl}$ buffer ( $\mathrm{pH} 7.6$ ) supplemented with $0.03 \%$ $\mathrm{H}_{2} \mathrm{O}_{2}$. The slides were counterstained with haematoxy-

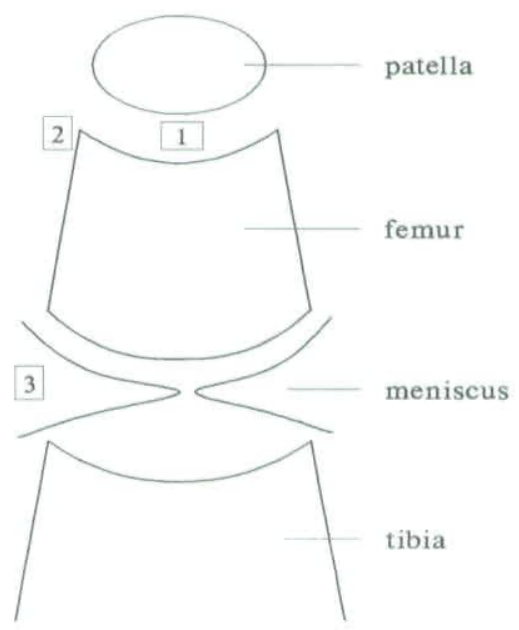

FIG. 1. Schematic presentation of a cross-section of a mouse knee joint showing the location of the regions in which the quantification of the various cell types was performed. 
TABLE I. Monoclonals used for the immunohistochemical characterization

\begin{tabular}{|c|c|c|c|}
\hline $\begin{array}{l}\text { Monoclonal } \\
\text { antibody }\end{array}$ & Antigen & Specificity & Reference \\
\hline $59 \mathrm{AD} 2.2$ & Thy-1 & $\begin{array}{l}\text { T lymphocytes, stem cells, } \\
\text { myeloid progenitors }\end{array}$ & 19 \\
\hline MT4 & CD4 & Th cells & 21 \\
\hline Lyt-2 & CD8 & $\mathrm{Tc} / \mathrm{s}$ cells & 19 \\
\hline Ra3-6B2 & B220 & B lymphocytes & 7 \\
\hline M5/114 & $I-A^{b / d / q}, I-E^{d / k}$ & $\mathrm{Ia}$ & 3 \\
\hline $\mathrm{F} 4 / 80$ & $\mathrm{~F} 4 / 80$ & macrophages & 1 \\
\hline
\end{tabular}

lin and embedded in glycerin/gelatin. In these sections the staining by the monoclonals used was easily distinguished from the endogenous peroxidase activity as the monoclonals showed a clear membrane or cytoplasmic staining whereas the granulocytes as a result of endogenous peroxidase activity appeared as darkbrown dots. Therefore, no attempt was made to block endogenous peroxidase activity.

\section{RESULTS}

Joint inflammations in $\mathrm{C} 57 \mathrm{BL} / \mathrm{Ka}$ mice were induced by local injection of $3 \times 10^{5}$ or $5 \times 10^{5}$ syngeneic, mBSA-specific cloned $\mathrm{T}$ cells. Thirty minutes to $1 \mathrm{~h}$ before injection of the cloned $\mathrm{T}$ cells, $30 \mu \mathrm{g} \mathrm{mBSA}$ had been injected in the right knee joint and $30 \mu \mathrm{g}$ OVA into the left knee joint. Fourteen days later in some of these mice a flareup reaction was provoked by injection of $30 \mu \mathrm{g}$ of the same antigens. The specific increase in knee thickness due to the inflammatory reactions is shown in Table II.

The joints of the mice of experiment (a) were histologically examined, whereas the joints of the mice of experiment (b) were used for immunohistochemical investigation.

\section{Histopathology}

The mean numbers of the various cell types counted in the sections of the joints $24 \mathrm{~h}$ after induction of the inflammation and $24 \mathrm{~h}$ after induction of the flare-up reaction are shown in Fig. 2. It demonstrates that the infiltrates in both the initial inflammation and the flare-up reaction were mainly granulocytic.

In the initial inflammation fibroblasts were found in a higher percentage in the region that was next to the menisci (region 3 ) than in the joint space between patella and femur (region 1). In region 3 , infiltration of the surrounding muscles by the inflammatory cells was found. Basophils and mast cells were only observed in regions 2 and 3. Not a single mast cell was observed in region 1 . Fibrin-like deposits were found in region 1. Plasma cells were not observed in these infiltrates.

During the flare-up reaction relatively more fibroblasts were found in region 3 than during the initial joint inflammation. Moreover, region 1 tended to contain more histiocytes in the flare-up reaction. Fig. 3(a) shows the inflammatory infiltrate in the right knee $24 \mathrm{~h}$ after induction of the inflammation. Fig. 3(b) shows a similar site $24 \mathrm{~h}$

TABLE II. Specific increase of knee thickness $( \pm$ SEM) of the mice used for histological and immunohistochemical examination

\begin{tabular}{lcccc}
\hline Expt & Injected & $\begin{array}{c}24 \text { hours } \\
\text { after } \\
\text { induction }\end{array}$ & $\begin{array}{c}14 \text { days } \\
\text { after } \\
\text { induction }\end{array}$ & $\begin{array}{c}24 \text { hours } \\
\text { after flare-up } \\
\text { induction }\end{array}$ \\
\hline (a) $\quad$ R: $5 \times 10^{5} \mathrm{mBSA}$ clone $+30 \mu \mathrm{g} \mathrm{mBSA}$ & $41.0 \pm 2.6$ & $2.1 \pm 2.0$ & $21.5 \pm 4.2$ \\
& L: $5 \times 10^{5} \mathrm{mBSA}$ clone $+30 \mu \mathrm{g} \mathrm{mBSA}$ & & \\
(b) $\quad$ R: $3 \times 10^{5} \mathrm{mBSA}$ clone $+30 \mu \mathrm{g} \mathrm{mBSA}$ & $56.3 \pm 4.7$ & $11.7 \pm 2.3$ & $23.5 \pm 4.0$ \\
& L: $3 \times 10^{5} \mathrm{mBSA}$ clone $+30 \mu \mathrm{g} \mathrm{mBSA}$ & & \\
\hline
\end{tabular}

Experiment (a) was the experiment of which the histological appearance is presented in Figs 2 and 3; experiment (b) was immunohistochemically investigated and is shown in Fig. 4. 


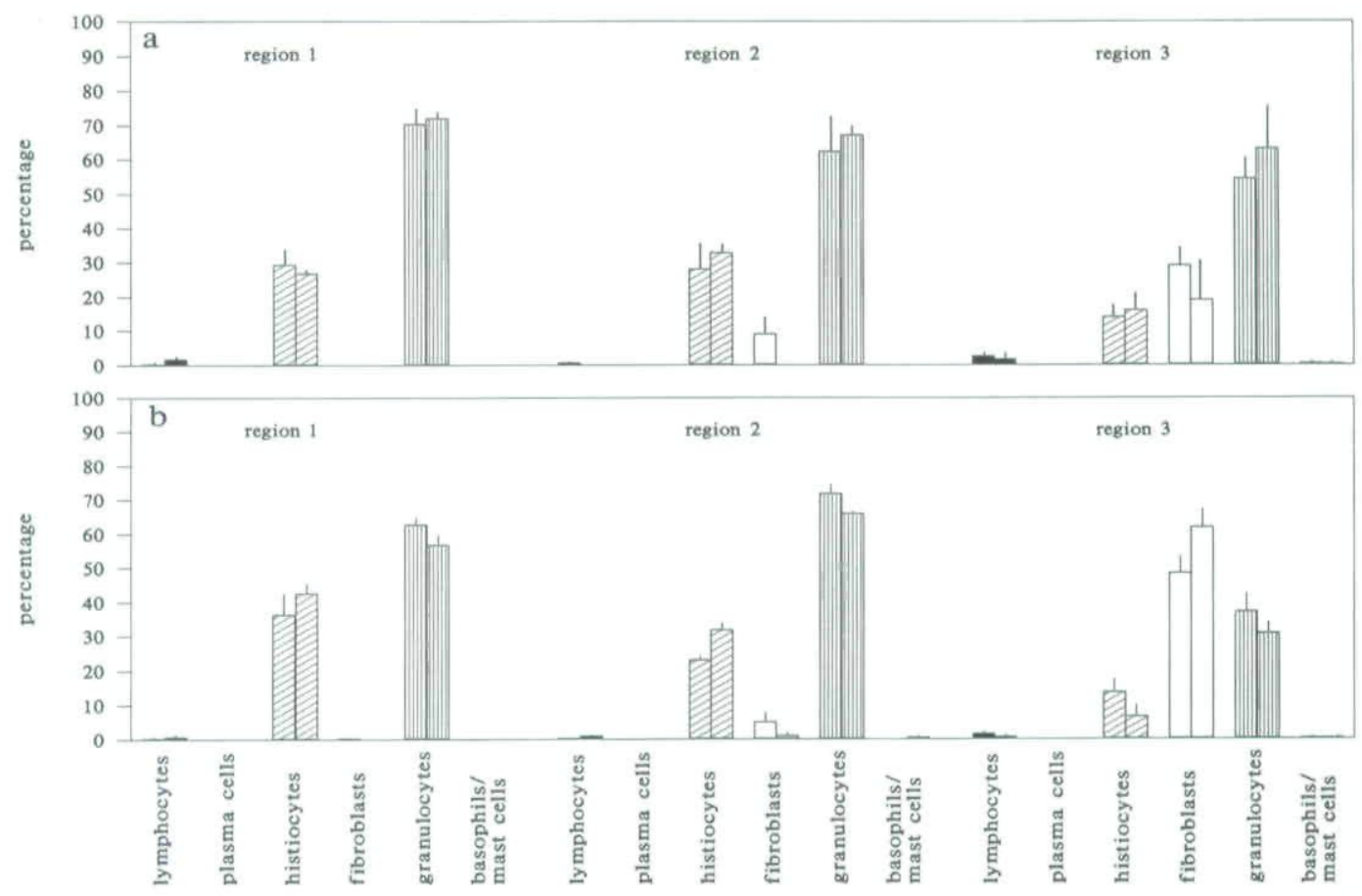

FIG. 2. Scores of the various cell types upon examination by two independent investigators of (a) the inflammatory infiltrate $24 \mathrm{~h}$ after the induction of inflammation by injection of $5 \times 10^{5} \mathrm{mBSA}$-specific cloned T cells and $30 \mu \mathrm{g}$ of $\mathrm{mBSA}$; and (b) $24 \mathrm{~h}$ after the induction of a flare-up reaction after a rechallenge with $30 \mu \mathrm{g} \mathrm{mBSA}$. The arithmetic mean of the counts of three or four levels \pm SEM is presented.

after induction of a flare-up reaction. The flareup infiltrate is shown in more detail in Fig. 3(c and d).

The very limited infiltrate 14 days after induction of the joint inflammation precluded reliable quantification of the different cell types. This infiltrate consisted of fibroblasts, histiocytes, some lymphocytes and mast cells. This is shown in Fig. 3(e).

The left knee joints of the mice served as a control as the cloned $\mathrm{T}$ cells were injected there together with the non-cross-reacting antigen ovalbumin. No inflammatory reaction was found in these control knee joints (data not shown). Fig. 3(b) shows the infiltrate in the right knee joint 14 days after the first induction of joint inflammation.

Twenty-four hours after the initial joint inflammation no cartilage destruction or hyperplasia of the synovial lining was observed. Thirteen days later some cartilage destruction was found, while the synovial lining was swollen, with focal syno- vial cell hyperplasia. The surrounding bone showed an increased remodelling activity.

\section{Immunohistochemistry}

The staining pattern produced by the monoclonal antibodies used (Table I) was analysed $24 \mathrm{~h}$ and 14 days after induction of the initial joint inflammation and 24 hours after induction of the flare-up reaction. Generally, the staining patterns after the initial induction of joint inflammation and in the flare-up reaction were much alike.

During flare-up several Thy-1+ cells were present in the joint space (Fig. 4a), mainly in region 3 as defined in Fig. 1, and in the region where the menisci were located. In the joint space between patella and femur almost no Thy-1 ${ }^{+}$cells were observed. Upon further examination the T cells appeared to be predominantly $\mathrm{MT}_{4}+$ (i.e. helper phenotype) (Fig. 4b), while only a few Lyt-2+ cells (i.e. cytotoxic/suppressor cell phenotype) were found (Fig. 4c). The T cells were not 

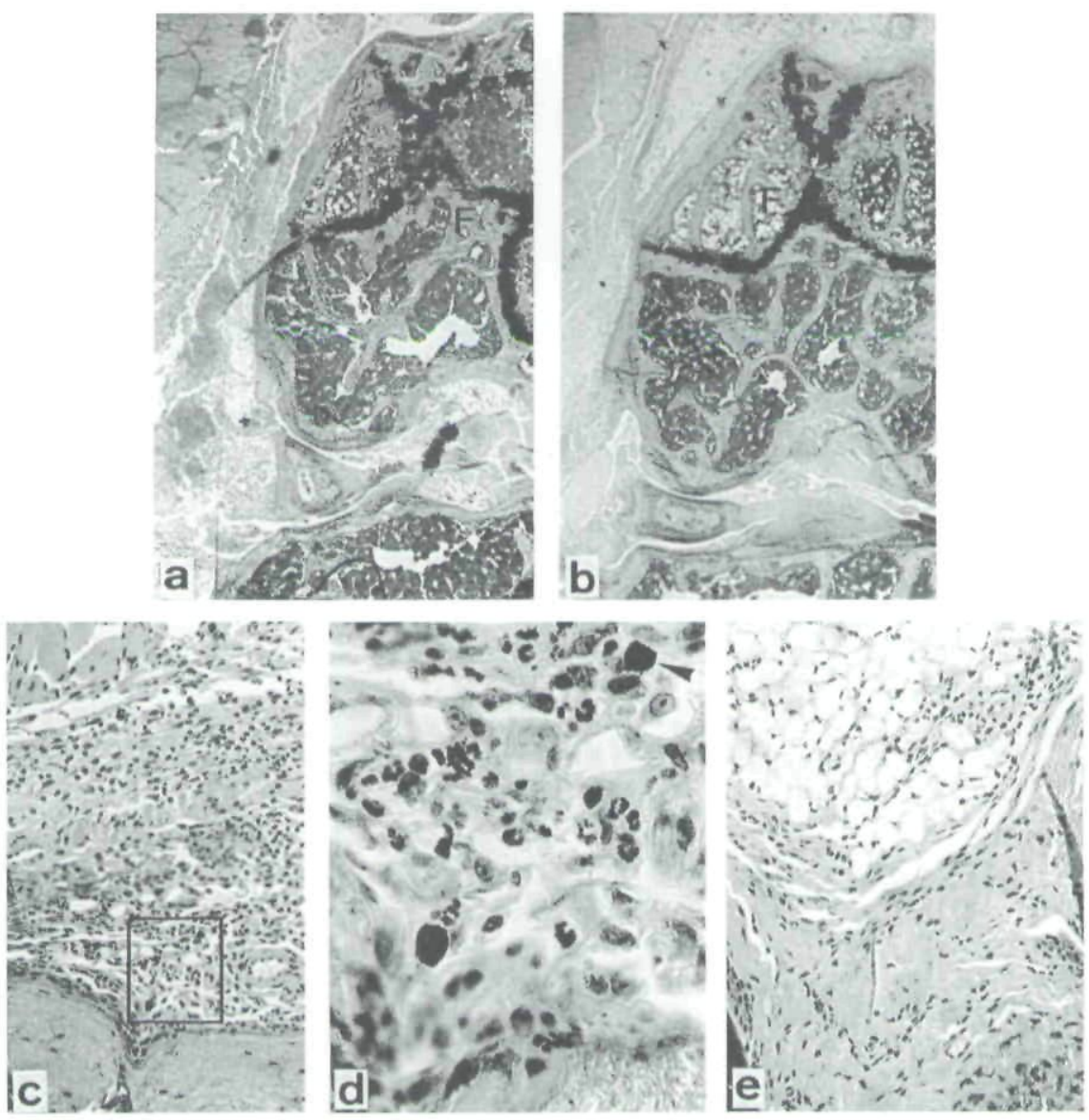

Fig. 3. Histological appearance of Giemsa-stained methylmethacrylate sections of the right knee joint of a mouse (a) $24 \mathrm{~h}$ after injection of $5 \times 10^{5} \mathrm{mBSA}$-specific cloned T cells and $30 \mu \mathrm{g}$ of mBSA, ( $\times 3.5)$; (b) $24 \mathrm{~h}$ after induction of a flare-up reaction by rechallenge with $30 \mu \mathrm{g} \mathrm{mBSA}$ ( $\times 3.5)$; (c) detail of (b) ( $\times 35)$; (d) detail of (c) $(\times 140)$; and (e) 14 days after induction of joint inflammation as described in (a) $(\times 35)$; $\mathrm{F}$ is femur; arrows indicate mast cells.

observed in the synovial lining. $\mathrm{Ia}^{+}$cells, determined by the monoclonal antibody M5/114, were found throughout the infiltrate (Fig. 4d). Occasionally cells of the synovial lining were found to be $\mathrm{Ia}^{+} . \mathrm{F} 4 / 80^{+}$cells were scattered throughout the infiltrate and were also present within the synovial lining membrane (Fig. 4e). Only a few B cells positive for the monoclonal Ra3-6B2 were found (not shown), but they were hard to discriminate as this monoclonal antibody gave a considerable background staining. Clusters of $\mathrm{T}$ cells (mostly Th with some $\mathrm{Tc} / \mathrm{s}$ ) in combination with $\mathrm{Ia}^{+}$cells and macrophages were found, with some tendency for perivascular localization. The small infiltrate at 14 days after induction of the inflammation was mainly situated in the region adjacent to the menisci. It consisted predominantly of Th lymphocytes and class II-positive cells. At this time the synovial lining was almost class II-negative. F4/80 positive cells were present in the infiltrate and in the synovial lining.

\section{DISCUSSION}

In the first part of this paper we presented the histology of joint inflammations and flare-up reactions induced by cloned $\mathrm{MT} 4{ }^{+} \mathrm{Lyt}-2-\mathrm{T}$ cells and the antigen recognized by the $\mathrm{T}$-cell clone. The cellular composition of the infiltrate cells in these inflammations was quantified by counting 


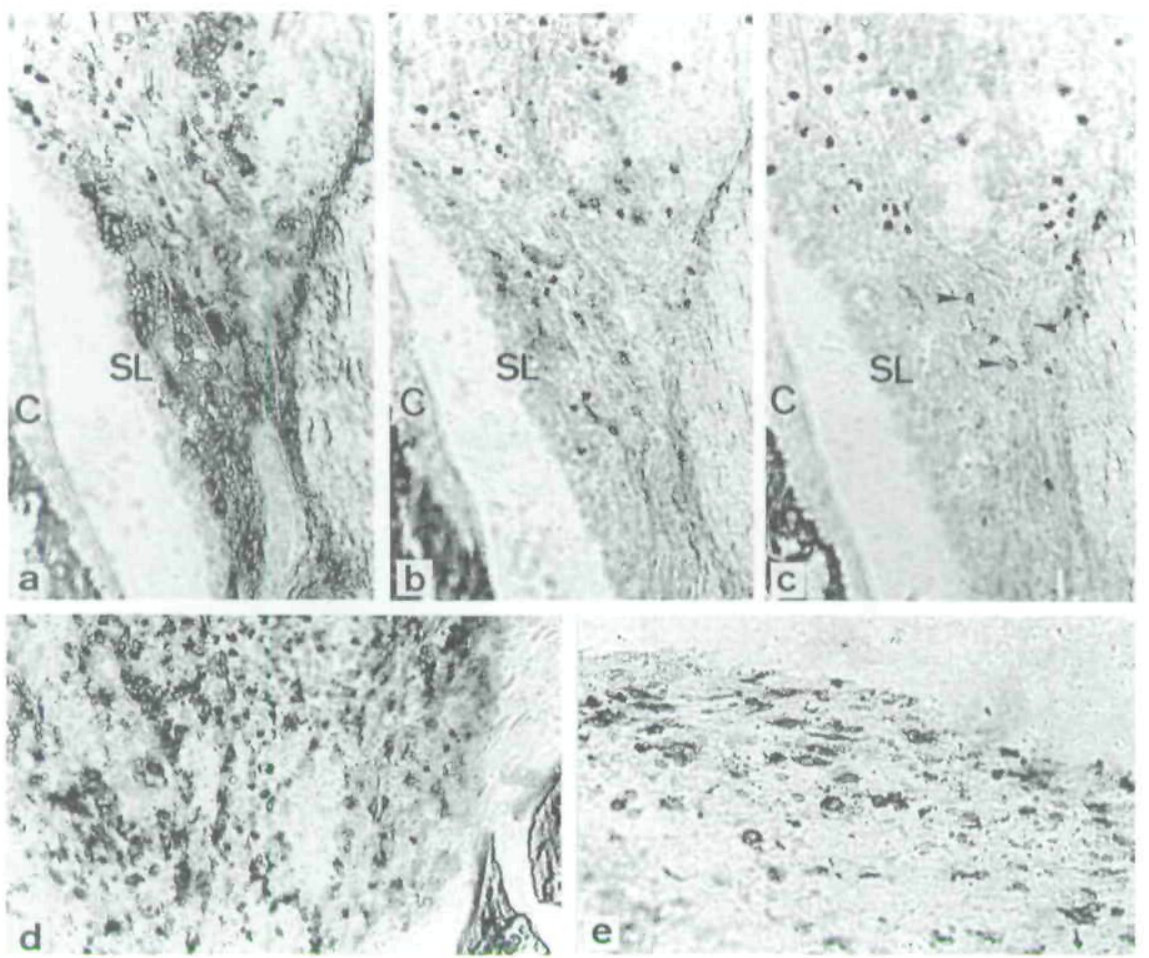

FiG. 4. Immunohistochemical appearance of the right knee joint of a mouse $24 \mathrm{~h}$ after induction of a flare-up reaction by a rechallenge with $30 \mu \mathrm{g} \mathrm{mBSA}$. The initial inflammation was induced by injection of $3 \times 10^{5} \mathrm{mBSA}$-specific cloned T cells and $30 \mu \mathrm{g} \mathrm{mBSA}$. The cryosections were stained by the monoclonals (a) 59AD2.2; (b) MT4; (c) Lyt-2; (d) M5/114; and (e) F4/80 (see Table I). Arrows indicate positive cells. SL, synovial lining; C, cartilage $(\times 35)$.

cell types in various sections of the joint in different regions. The infiltrates observed $24 \mathrm{~h}$ after the initial induction of the joint inflammation and $24 \mathrm{~h}$ after the flare-up reaction were much alike. In both situations granulocytes predominated. The infiltrate observed 14 days after induction of the inflammation was more histiocytic and characterized by fibrosis. The infiltrate was mainly devoid of granulocytes.

Probably after a second administration of the antigen the retained $T$ cells in the joints are restimulated and again start to produce lymphokines that attract granulocytes. In the flare-up reaction somewhat more histiocytes and fibroblasts were found, probably as the result of the longer existing inflammation. In the flare-up reaction we observed some cartilage destruction with a 'ruffled' appearance. This cartilage destruction was not described in our previous papers $[14,15]$. Probably the cartilage destruction depends on the intensity of the inflammation during the initial induction stage.

Subsequently we investigated the immunohistochemistry of the joint inflammations induced by the cloned helper $\mathrm{T}$ cells and the antigen. In this examination the initial inflammation and the flare-up reaction were also much alike. Quite a few $T$ cells were observed, predominantly of the helper phenotype. Experiments are in progress using Thy-1 congenic mice to investigate how many of these $\mathrm{T}$ cells belong to the cloned $\mathrm{T}$ cells that we injected into the joint or are derived from them. The number of Thy-1+ cells appeared to be higher than the number of $\mathrm{MT}^{+}$cells plus the number of Lyt $-2^{+}$cells, which might be caused by the staining of myeloid progenitor cells by 59AD2.2 monoclonal. Moreover the number of T cells that we observed after immunohistochemical staining was higher than the number of lymphocytes that we determined histologically. 
So, probably we overestimated the number of $\mathrm{T}$ lymphocytes in the former study.

The Ia expression on various cell types was superfluous, and the synovial lining also contained $\mathrm{Ia}^{+}$cells. This Ia expression is probably due to the release of gamma-interferon by the cloned $\mathrm{MT}^{+}, \mathrm{Lyt}-2^{-} \mathrm{T}$ cells [25]. Moreover several lymphokines that can increase the Ia expression can be released in the infiltrate. F4/ $80^{+}$cells were scattered throughout the infiltrate. Cells of the synovial lining were also stained by $\mathrm{F} 4 / 80$. We were unable to discriminate between the types I, II, and III cells in the synovium, as defined by Burmester [6] and studied by Dijkstra et al. [8] and Verschure et al. [31] in the AIA model in the rat, as we did not apply monoclonal antibodies specific for these subpopulations. We assume that the F4/80 monoclonal antibody mainly stains the type I (macrophage-like) cells of the synovial lining.

Clusters of cells were found at several places in the infiltrate in which T cells (mainly Th and some $\mathrm{Tc}$ ) and $\mathrm{Ia}^{+}$cells were present as well as some B cells. In these clusters presentation of antigen probably takes place [8]. The predominance of helper $\mathrm{T}$ cells is in line with the data reported in the adjuvant arthritis model [18] and in the collagen type II model in mice [10] and rats [11]. Furthermore, in the adjuvant arthritis model it has been shown that a depletion of the $\mathrm{Tc} / \mathrm{s}$ cells did not affect the disease course [18]. In biopsy specimens or cell suspensions from synovial effusions in man, a predominance of $\mathrm{CD} 8^{+}$cells has been found $[9,12]$. The $\mathrm{CD}^{+}{ }^{+}$cell population has been reported to include the activated cell population [2]. Others have found predominantly activated $\mathrm{CD}^{+}{ }^{+}$cells in the synovial membrane [22]. Kurakosa \& Ziff [17] state that the ratio of CD4 ${ }^{+}$ to $\mathrm{CD} 8{ }^{+} \mathrm{T}$ cells in the rheumatoid synovium varies with the type of area examined. Still, the occurrence of $\mathrm{CD}_{4}+$ cells is more in line with the DTH nature [13] of arthritis in experimental models as well as in human rheumatoid diseases.

In conclusion, we have shown that injection of cloned $\mathrm{T}$ cells of the helper phenotype and the corresponding specific antigen can result in a joint inflammation that is histologically and immunohistochemically comparable to the inflammations observed in the AIA model in immunized animals $[8,31]$ and the initial stages of human rheumatoid arthritis [32]. Moreover, the flare-up reactions of joint inflammations provoked by reintroduction of the specific antigen appeared histologically and immunohistochemically comparable to the infiltrates of the initial inflammations. Thus in mice only $\mathrm{T}$ cells and the specific antigen can account for the flare-up reactions that resemble the exacerbations occurring in human rheumatic diseases.

\section{ACKNOWLEDGMENTS}

The assistance of Mrs Ilse Vogels and Mr Ed Döpp in the preparation of the immunohistochemical slides is gratefully acknowledged. We also thank Professor Dr O. Vos and Dr W. van Ewijk for continuous support, Mr Tar van Os for expert photography, and Ms Geertje de Korte for secretarial assistance.

\section{REFERENCES}

1 Austyn, J.M. \& Gordon, S. F4/80, a monoclonal antibody directed specifically against the mouse macrophage. Eur. J. Immunol. 11, 805, 1981.

2 Bergroth, V., Konttinen, Y.T., Nykanen, P., von Essen, R. \& Koota, K. Proliferating cells in the synovial fluid in rheumatic disease. Scand. J. Immunol. 22, 383, 1985.

3 Bhattacharya, A., Dorf, M.E. \& Springer, T.A. A shared allo-antigenic determinant on Ia antigens encoded by the I-A and I-E subregions: evidence for I region duplication. J. Immunol. 127, 2488, 1981.

4 Brackertz, D., Mitchell, G.F. \& Mackay, I.F. Antigen-induced arthritis in mice. I. Induction of arthritis in various strains of mice. Arthritis Rheum. 20, 841,1977

5 Brackertz, D., Mitchell, G.F., Vadas, M.A. \& Mackay, I.R. Studies on antigen-induced arthritis in mice. III. Cell and serum transfer experiments. $J$. Immunol. 118, 1645, 1977.

6 Burmester, G.R., Dimitriu-Bona, A., Waters, A.J. \& Winchester, R.J. Identification of three major synovial lining cell populations by monoclonal antibodies directed to Ia antigens and antigens association with monocytes/macrophages and fibroblasts. Scand. J. Immunol. 17, 69, 1983.

7 Coffman, R.L. Surface antigen expression and immunoglobulin gene rearangement during mouse pre-B cell development. Immunol. Rev. 69, 5, 1982.

8 Dijkstra, C.D., Döpp, E.A., Vogels, I.M.C. \& Van Noorden, C.J.F. Macrophages and dendritic cells in antigen-induced arthritis: an immunohistochemical study using cryostat sections of the whole knee joint of rat. Scand. J. Immunol. 26, 513, 1987.

9 Duke, O., Panayi, G.S., Janossy, G., Poulter, L.W. \& Tidman, N. Analysis of $\mathrm{T}$ cell subsets in the peripheral blood and synovial fluid of patients with rheumatoid arthritis by means of monoclonal antibodies. Ann. Rheum. Dis. 42, 357, 1983.

10 Holmdahl, R., Jonsson, R., Larsson, P. \& Klares- 
kog, L. Early appearance of activated $\mathrm{CD} 4^{+} \mathrm{T}$ lymphocytes and class II antigen-expressing cells in joints of DBA/1 mice immunized with type II collagen. Lab. Invest. 58, 53, 1988.

11 Holmdahl, R., Rubin, K., Klareskog, L., Dencker, L., Gustafson, G. \& Larsson, E. Appearance of different lymphoid cells in synovial tissue and in peripheral blood during the course of collagen IIinduced arthritis in rats. Scand. J. Immunol. 21, 197. 1985.

12 Jahn, B., Burmester, G.R., Gramatzki, M., Weseloh, G., Stock, P. \& Kalden, J.R. Intraarticular T lymphocytes in monoarticular and oligoarticular inflammatory joint diseases. J. Rheumatol. 13, 254. 1986.

13 Klareskog, L., Forsum, U., Scheynius, A., Kabelitz, D. \& Wigzell, H. Evidence in support of a selfperpetuating HLA-DR-dependent delayed-type cell reaction in rheumatoid arthritis. Proc. Natl. Acad. Sci. USA 79, 3632, 1982.

14 Klasen, I.S., Ladestein, R.M.T., Donselaar, I.G., Van den Berg, W.B., Tees, R. \& Benner, R. Joint inflammations in mice induced by a MT4 $4^{+}$, Lyt $^{-} \mathrm{T}$ cell clone. Characteristics and flare-up reactions. $J$. Immunol. 139, 3275, 1987.

15 Klasen, I.S., Ladestein, R.M.T., Van den Berg. W.B. \& Benner, R. Requirements for flare-up reactions of joint inflammations in mice induced by cloned MT4+ ${ }^{+}$Lyt-2-T cells. Arthritis Rheum. 32, 330, 1989.

16 Kruijsen, M.W.M., Van den Berg, W.B., Van de Putte, L.B.A. \& Van den Broek, W.J.M. Detection and quantification of experimental joint inflammation in mice by measurement of ${ }^{99 \mathrm{~m}} \mathrm{Tc}$-pertechnetate uptake. Agents Actions 11, 640, 1981.

17 Kurosaka, M. \& Ziff, M. Immunoelectron microscopic study of the distribution of T cell subsets in rheumatoid synovium. J. Exp. Med. 158, 1191, 1983.

18 Larsson, P., Holmdahl, R., Dencker, L. \& Klareskog, L. In vivo treatment with W3/13 (anti-pan T) but not with Ox8 (anti-suppressor/cytotoxic T) monoclonal antibodies impedes the development of adjuvant arthritis in rats. Immunology 56, 383, 1985.

19 Ledbetter, J.A. \& Herzenberg, L.A. Xenogeneic monoclonal antibodies to mouse lymphoid differentiation antigens. Immunol. Rev. 47, 63, 1979.

20 Lens, J.W., Van den Berg, W.B., Van de Putte, L.B.A. \& Van den Bresselaar, L. Flare-up of antigen-induced arthritis in mice after challenge with oral antigen. Clin. Exp. Immunol. 58, 364, 1984.

21 Pierres, A., Naquet, P., Van Agthoven, A., Bekkoucha, F., Denizot, F., Mishal, Z., Schmitt-Verhulst, A.M. \& Pierres, M. Rat anti-mouse T 4 monoclonal antibody (H129.19) inhibits the proliferation of Iareactive $\mathrm{T}$ cell clones and delineates phenotypically distinct $\left(\mathrm{T} 4^{+}, \mathrm{Lyt} 2,3^{-}\right.$and $\left.\mathrm{T} 4^{-}, \mathrm{Lyt} 2,3^{+}\right)$subset among anti-Ia cytotoxic T cell clones. J. Immunol. 132, 2775, 1984.

22 Poulter, L.W., Duke, O., Panayi, G.S., Hobbs, S., Raftery, M.J. \& Janossy, G. Activated T lymphocytes of the synovial membrane in rheumatoid arthritis and other arthropathies. Scand. J. Immunol. 22, 683, 1985.

23 Rijntjes, N.V.M., Van de Putte, L.B.A., Van der Pol, M. \& Guelen, G.J.M. Cryosectioning of undecalcified tissues for immunofluorescence. J. Immunol. Methods 30, 263, 1979.

24 Schreier, M.H., Iscove, N.N., Tees, R., Aarden, L. \& Von Boehmer, H. Clones of killer and helper T cells: growth requirements, specificity and retention of function in long-term culture. Immunol. Rev. 51, $315,1980$.

25 Steeg, P.S., Moore, R.N., Johnson, H.M. \& Oppenheim, J.J. Regulation of murine Ia antigen expression by a lymphokine with immune interferon activity. J. Exp. Med. 156, 1780, 1982.

26 Te Velde, J., Burkhardt, R., Kleiverda, K., Leenheers-Binnendijk, L. \& Sommerfeld, W. Methylmethacrylate as an embedding medium in histopathology. Histology 1, 319, 1977.

27 Van Beusekom, H.J., Van de Putte, L.B.A., Van den Berg, W.B., Van den Broek, W.J.M. \& Buijs, W.C.A.M. Antigen handling in antigen induced joint inflammation: kinetics of a second intraarticularly injected dose of antigen in an already established antigen-induced joint inflammation. Immunology 44, 153, 1981.

28 Van den Berg. W.B., Van de Putte, L.B.A., Zwarts, W.A. \& Joosten, L.A.B. Electrical charge of the antigen determines intraarticular antigen handling and chronicity of arthritis in mice. J. Clin. Invest. 74, $1850,1984$.

29 Van de Putte, L.B.A., Lens, J.W., Van den Berg. W.B. \& Kruijsen, M.W.M. Exacerbation of antigeninduced arthritis after challenge with intravenous antigen. Immunology 49, 161, 1983.

30 Van Noorden, C.J.F. \& Vogels, I.M.C. Enzyme histochemical reactions in unfixed and undecalcified cryostat sections of mouse knee joints with special reference to arthritic lesions. Histochemistry 86, 127, 1986.

31 Verschure, P.J., Van Noorden, C.J.F. \& Dijkstra, C.D. Macrophages and dendritic cells during the early stages of antigen-induced arthritis in rats: immunohistochemical analysis of cryostat sections of whole knee joint. Scand. J. Immunol. 29, 371, 1989.

32 Zvaifler, N.J. Pathogenesis of the joint disease of rheumatoid arthritis. Am. J. Med. 75 (Suppl.), 3, 1983.

Received 2 February 1990

Accepted in revised form 15 May 1990 
This document is a scanned copy of a printed document. No warranty is given about the accuracy of the copy. Users should refer to the original published version of the material. 